American Journal of Applied Sciences 6 (4): 594-600, 2009

ISSN 1546-9239

(C) 2009 Science Publications

\title{
Comparative Studies of the Determination of Divalent Cadmium, Lead and Copper in the Boiling Medicinal Herbs by Stripping Voltammetry and by Atomic Absorption Spectrometry
}

\author{
Ahmed Hassan and Jamal A. Mayouf \\ Department of Chemistry, Faculty of Science, Assiut University, 71516, Assiut, Egypt
}

\begin{abstract}
Cadmium, lead and copper were determined in ten Libyian boiling medicinal herbs samples by differential pulse anodic stripping voltammetry as well as by atomic absorption spectrometry. Voltammetric method was done at Hanging Mercury Dropping Electrode (HMDE) in Briton-Robinson buffer solution of $\mathrm{pH} \sim 2.1$ at $25 \pm 0.1^{\circ} \mathrm{C}$. The sample preparation was carried out by boiling $2.0 \mathrm{~g}$ of a finely pulverized plant sample for $10 \mathrm{~min}$, cooled, filtered and completed to $50 \mathrm{~mL}$ measuring flask by deionized water. The optimal preconcentration potentials and times for the detection of these metal ions in all sample solutions have been studied. The concentration of each metal ion was determined by the standard addition method. The statistical parameters i.e. slope, standard deviation, correlation coefficient and confidence have been calculated. The levels of $\mathrm{Cd}(\mathrm{II}), \mathrm{Pb}(\mathrm{II})$ and $\mathrm{Cu}(\mathrm{II})$ ranged from $0.006-0.103,0.205-1.751$ and $0.198-2.124 \mu \mathrm{g} \mathrm{g}^{-1}$ respectively. Copper was determined by Flame Atomic Absorption Spectrometry (FAAS) and the mean level was ranged from 0.202-2.010 $\mathrm{gg} \mathrm{g}^{-1}$. On the other hand the mean levels obtained for determination of cadmium and lead by Graphite Furnace Atomic Absorption Spectrometry (GFAAS) ranged from 0.006 to 0.085 and from $0.220-1.850 \mu \mathrm{g} \mathrm{g}^{-1}$ respectively.
\end{abstract}

Key words: Cadmium, lead, copper, analytical determination, medicinal herbs

\section{INTRODUCTION}

Cadmium is one of the few elements that have no constructive purpose in the human body. This element and its compound solution are extremely toxic even in low concentration and will bioaccumulation in organisms and ecosystems. One possible reason for its toxicity is its interference with the action of zinccontaining enzymes. Cadmium may also interferes with biological processes containing magnesium and calcium $^{[1,2]}$. Its toxicity threatens the health of the body by weakened immune system, kidney disease and live damage, effects may include emphysema, cancer and a shortened life $\operatorname{span}^{[1,3-8]}$.

Lead has no biological role in the body. Most lead poisoning symptoms are thought to occur by interfering with an essential enzyme Delta-aminolevulinic acid dehydratase, ALAD, (is a zinc-binding protein which is important in the biosynthesis of heme, the cofactor found in hemoglobin) ${ }^{[9,10]}$. It inhibits several enzymes critical to the synthesis of heme, causing a decrease in blood hemoglobin and interferes with a hormonal form of vitamin D, which affects multiple processes in the body, including cell maturation and skeletal growth. Lead can also cause hypertension, reproductive toxicity and developmental effects. Lead exposure can lead to renal effects such as fanconi-like syndromes, chronic nephropathy and gout ${ }^{[11-15]}$.

Copper is both vital and toxic for many biological system, it is critical for energy production in the cells, also involved in nerve conduction, connective tissue, the cardiovascular system and the immune system and excess copper may be absorbed in the intestinal tissues which lead to intestinal disorders, impaired healing and reduced resistance to infections ${ }^{[16-18]}$.

Recently, several methods of analysis were done for determination of cadmium, lead and copper, e.g. by neutron activation analysis ${ }^{[19,20]}$, inductively coupled plasma atomic emission spectrometry ${ }^{[21-24]}$, inductively coupled plasma mass spectrometry ${ }^{[25,26]}$, spectrophotometry ${ }^{[27,28]}$ atomic absorption spectroscopy ${ }^{[19]}$ atomic absorption spectrometry ${ }^{[24,25,29-}$ ${ }^{31]}$, electrothermal atomic absorption spectroscopy ${ }^{[32]}$, electrothermal atomic absorption spectrometry ${ }^{[26,33]}$, atomic absorption spectrophotometry ${ }^{[34,35]}$, flame atomic absorption spectrometry and flame atomic

Corresponding Author: Ahmed Hassan, Department of Chemistry, Faculty of Science, Assiut University, 71516, Assiut, Egypt Tel: 002/0882318504 Fax: 002/0882342708 
Am. J. Applied Sci., 6 (4): 594-600, 2009

emission spectrometry ${ }^{[23,33,36,37]}$, a signal volta-mmetric sweep at $\mathrm{pH} 4.6^{[38]}$. Cadmium and lead were also determined in medicinal plants by differential pulse anodic stripping after preconcentration of the metals in $0.8 \mathrm{M} \mathrm{HCl}$ at $0.73 \mathrm{~V}$ for $180 \mathrm{sec}$. and the sample preparation was carried out by dry-ashing $1.0 \mathrm{~g}$ of plant sample for $2.5 \mathrm{~h}$ at $500^{\circ} \mathrm{C}^{[39]}$. This prompted us to study the determination of cadmium, lead and copper by differential pulse anodic stripping voltammetry as well as by flame atomic absorption spectrometry of copper and graphite furnace atomic absorption spectrometry of cadmium and lead in buffer solution of $\mathrm{pH} \sim 2.1$ as the extension of a series of our investigations ${ }^{[40-43]}$ for determination of industrial and biological important elements.

\section{MATERIAL AND METHODS}

Apparatus: All glassware was soaked in 10\% (v/v) $\mathrm{HNO}_{3}$ for $24 \mathrm{~h}$ and rinsed three times with distilled water and then in redistilled water before use.

Polarographic analyzer: Differential pulse anodic stripping voltammograms were recorded with an EG and G. Princeton Applied Research Crop. (PAR; Princeton, NJ) model 264 A stripping analyzer, coupled with a PAR 303A Hanging Mercury Drop Electrode (HMDE). The polarographic cell (PAR Model K0060) was fitted with $\mathrm{Ag} / \mathrm{AgCl}$ saturated $\mathrm{KCl}$ and used as a reference electrode with a platinum wire as a counter (auxiliary) electrode. A PAR 305 magnetic stirrer was connected to the 303 A HMDE. A PAR Model RE 0151X-Y recorder was used to collect experimental data. Before measurements the sample solution was deaereated by bubbling for $16 \mathrm{~min}$ with nitrogen. During measurements, an inert atmosphere over the solution was maintained by flushing with nitrogen. During the deposition step, the solution was stirred automatically, followed by a quiescent period of $15 \mathrm{sec}$. before scanning.

- $\mathrm{pH}$ was measured with a Fischer Scientific (Pittsburgh, PA, USA) Digital pH Meter Model 810

- GBC 906 atomic absorption spectrophotometer was used for $\mathrm{Cu}(\mathrm{II})$ measurement at wavelength $324.7 \mathrm{~nm}$, band-pass $0.7 \mathrm{~nm}$ and lamp current $6.0 \mathrm{~mA}$ and a AA-6800 Shimadzu (GFA-EX7) Graphite Furnace atomic absorption spectrophotometer was used for $\mathrm{Cd}(\mathrm{II})$ and $\mathrm{Pb}$ (II) determination at band-pass $0.7 \mathrm{~nm}$, lamp current $8.0 \mathrm{~mA}$ and wavelengths 228.9 and $283.2 \mathrm{~nm}$ respectively
Solution and reagents: All reagents are of analytical grade. The following solutions were prepared with bidistilled water.

- Solution of each $\mathrm{Cd}(\mathrm{II}), \mathrm{Pb}(\mathrm{II})$ and $\mathrm{Cu}(\mathrm{II})$ were prepared respectively by dissolving the required amounts of $\mathrm{Cd}(\mathrm{NO} 3) 2.4 \mathrm{H} 2 \mathrm{O}, \mathrm{Pb}(\mathrm{NO} 3) 2$ and $\mathrm{Cu}(\mathrm{NO} 3) 2.2 \mathrm{H} 2 \mathrm{O}$ in bidistilled water. The resulting solutions were then standardized ${ }^{[44]}$. Solutions of lower concentrations were prepared by accurate dilution

- Briton-Robinson buffer solution was prepared by dissolving $201 \mu \mathrm{L}$ glacial acetic acid (AnalaR), $240 \mu \mathrm{L}$ phosphoric acid (Merck) and $433 \mathrm{mg}$ boric acid (BDH) in $500 \mathrm{~mL}$ measuring flask with bidistilled water ${ }^{[45]}$

- Ten medicinal herbs samples were collected from Libyian Jamahyria as shown in Table 1. Dried herbal samples were cut into small pieces and then ground into powder. To prepare the boiling of the herbs, $2 \mathrm{~g}$ of sample was placed in a beaker containing $40 \mathrm{~mL}$ of bidistilled water and boiled for $10 \mathrm{~min}$. After cooling, the extract was filtered through the Whatman No. 541 filter paper and the filtrate was diluted to $50 \mathrm{~mL}$ with bidistilled water. Each resulting solution was treated with $10 \mathrm{~mL}$ of concentrated nitric acid (AnalaR) and heated nearly dry (repeated three times). This procedure was repeated with $10 \mathrm{~mL}$ of a $1: 1 \quad\left(\mathrm{HNO}_{3} / \mathrm{HClO}_{4}\right)$ mixture until complete mineralization the cold residue was dissolved in $1 \mathrm{~mL}$ of $1 \mathrm{M}$ nitric acid and diluted to $10 \mathrm{ml}$ with bidistilled water. Nitric acid concentration was adjusted at $0.01 \mathrm{M}$. A control reagent blank was prepared in the same manner to determine the ultra trace impurities of the metal ions

Analytical procedure: The following parameters were used to perform differential pulse anodic stripping voltammetry (DPASV). Scan rate $10 \mathrm{mVs}^{-1}$ with duration for $1 \mathrm{sec}$. and pulse amplitude $(\Delta \mathrm{E}) 25 \mathrm{mV}$.

For determination of $\mathrm{Cd}(\mathrm{II}), \mathrm{Pb}$ (II) and $\mathrm{Cu}(\mathrm{II})$ in medicinal herb samples in the same cell. $5 \mathrm{~mL}$ of each sample solution and $1 \mathrm{~mL}$ Briton-Robinson buffer solution were transferred to the electrolysis cell and diluted to $10 \mathrm{~mL}$ using bidistilled water $(\mathrm{pH} \sim 2.1)$. The solution was deaereated by passing pure nitrogen for $16 \mathrm{~min}$. The deposition potential were controlled at ($0.75,-0.55$ and $-0.25 \mathrm{~V}$ vs. $\mathrm{Ag} / \mathrm{AgCl}$ saturated $\mathrm{KCl}$ respectively) and applied to a fresh mercury drop while the solution was stirred. After the deposition step and further $15 \mathrm{sec}$. (equilibrium time) the voltammogram was recorded. 
Am. J. Applied Sci., 6 (4): 594-600, 2009

Table 1: Characteristics of the boiling samples.

\begin{tabular}{|c|c|c|c|}
\hline Sample No. & Name & Scientific name & Part used \\
\hline $\mathrm{B}_{1}$ & Camel's hay sweet rush & $\begin{array}{l}\text { Cymbopogen schoenanthus }(\mathrm{L}) \text { spreng } \\
\text { Andropogen schoenanthus } \mathrm{L} \text {. }\end{array}$ & The whole herb \\
\hline $\mathrm{B}_{2}$ & Juniper, common juniper & Juniperus communis $\mathrm{L}$. & Fresh ripe berries \\
\hline $\mathrm{B}_{3}$ & Rosemary, common rosemary & Rosmarinus officinalis L. & Ieaves and flowering tops \\
\hline $\mathrm{B}_{4}$ & Rune, common rue, herb of grace & Ruta graveolens $\mathrm{L}$. & Leaves \\
\hline $\mathrm{B}_{5}$ & Stinging nettle, small nettle & Urtica urens $\mathrm{L}$. & The whole plant \\
\hline $\mathrm{B}_{6}$ & Sweet marjoram & $\begin{array}{l}\text { Origanum majorana L., Majorana } \\
\text { hortensis moen }\end{array}$ & $\begin{array}{l}\text { The flowering plant } \\
\text { without roots }\end{array}$ \\
\hline $\mathrm{B}_{7}$ & Tubercled rue & Haplophyllum tuberculatum (forssk) A. Juss & The whole herb without roots \\
\hline $\mathrm{B}_{8}$ & White horehound, Horehound & Marrubium Vulgare L. & $\begin{array}{l}\text { The herb while flowering } \\
\text { without roots }\end{array}$ \\
\hline $\mathrm{B}_{9}$ & Sohbetelhosan & Scorphularia canina $\mathrm{L}$. & The whole herb without roots \\
\hline $\mathrm{B}_{10}$ & Worm seed & Artemisia herb-alba & Flowering heads \\
\hline
\end{tabular}

Different concentration from the standard metal ion (individually) were added to the cell using an automatic pipette (Volac 10-100 $\mu \mathrm{L}$ ), while keeping the deposition time constant. The solution was stirred and purged with nitrogen for $1 \mathrm{~min}$. after each spike. The concentration of each $\mathrm{Cd}(\mathrm{II}), \mathrm{Pb}(\mathrm{II})$ and $\mathrm{Cu}$ (II) in the electrolytic cell were calculated in the sample solutions by using standard addition method, $\left(\mathrm{C}_{\mathrm{c}}\right)$. Then the concentration in $\mu \mathrm{g} \mathrm{g}^{-1}$ of each medicinal herb sample was calculated by the following equation: $\mathrm{C}$ in $\mu \mathrm{g} \mathrm{g}^{-1}=\mathrm{C}_{\mathrm{c}} \times 10^{7} \times$ at wt of the metal ion. For cadmium and lead the digested sample solution were treated with concentrated $\mathrm{HNO}_{3}$ before determination by graphite furnace AAS and the treated sample solution of copper were determined by Flame AAS. The metals were quantified against standard curves prepared at the day of the analysis.

\section{RESULTS AND DISCUSSION}

In order to set the optimal condition of the three cations, preliminary measurements were made to obtain the highest peak signal for metal ions $\mathrm{Cd}(\mathrm{II}), \mathrm{Pb}$ (II) and $\mathrm{Cu}$ (II) in solution samples. It was noticed that, BritonRobinson buffer solution ( $\mathrm{pH} \sim 2.1$ ) gave promising results for the determination of $\mathrm{Cd}, \mathrm{Pb}$ and $\mathrm{Cu}$ ions. The effect of deposition potential of each metal ion was studied and it was observed that the highest and best shape peaks for $\mathrm{Cd}^{2+}, \mathrm{Pb}^{2+}$ and $\mathrm{Cu}^{2+}$ were obtained at deposition potentials $-0.75,-0.55$ and $-0.25 \mathrm{~V}$ vs. $\mathrm{Ag} / \mathrm{AgCl} / \mathrm{KCl}_{\text {sat. }}$ respectively.

The effect of deposition time on the oxidation peak signals of these metal ions was examined. Figure 1 shown differential pulse anodic stripping voltammograms of $\mathrm{Cu}$ (II) in Rosemary sample $\left(\mathrm{B}_{3}\right)$ in buffer solution at different deposition times. The optimal deposition times were selected for these metal ions of all sample solutions in a manner that linear relation must be established between deposition times and current signals and listed in Table 2-4.

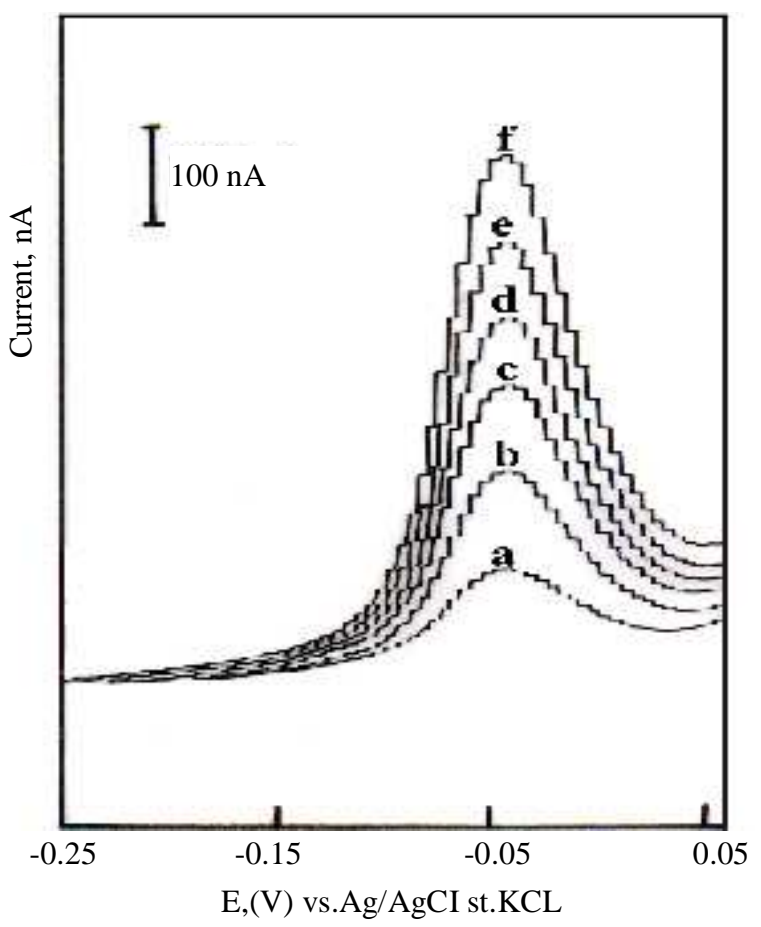

Fig. 1: DPAS Voltammograms of $\mathrm{Cu}(\mathrm{II})$ in $\mathrm{B}_{3}$ sample in presence of $0.028 \mathrm{M}$ Briton-Robinson buffer solution, $\mathrm{pH} \sim 2.1$ at deposition potential $-0.25 \mathrm{~V}$ and different deposition times. (a): $0 \mathrm{sec}, \quad$ (b): $5 \mathrm{sec}, \quad$ (c): $10 \mathrm{sec}$, (d): $15 \mathrm{sec},(\mathrm{e}): 20 \mathrm{sec},(\mathrm{f}): 25 \mathrm{sec}$

DPAS voltammetric determination of $\mathrm{Pb}(\mathrm{II})$ : Figure 2 shows the differential pulse anodic stripping voltammograms of $\mathrm{B}_{3}$ sample solution in absence and in presence of standard lead nitrate. The plots of peak current against concentration are given in Fig. 3. From the interception of this line with the concentration axis at zero current signal gives the concentration of $\mathrm{Pb}^{2+}$ in the voltammetric cell for each sample. After correction for the background current of blank experiments. The 
Am. J. Applied Sci., 6 (4): 594-600, 2009

Table 2: Lead content of different boiling samples (a mean value \pm standard deviation for $\mathrm{n}=5$ at $95 \%$ confidence level)

\begin{tabular}{|c|c|c|c|c|c|c|c|c|}
\hline \multirow{3}{*}{$\begin{array}{l}\text { Sample } \\
\text { No. }\end{array}$} & \multirow{3}{*}{$\begin{array}{l}\mathrm{T}_{\mathrm{d}} \\
(\mathrm{sec})\end{array}$} & \multirow{3}{*}{$\begin{array}{l}\text { Lead } \\
\text { content } \\
(\text { mean } \pm \text { SD) } \\
\mu \mathrm{g} \mathrm{g}^{-1} \\
(\mathrm{DPSAV})\end{array}$} & \multicolumn{5}{|c|}{ Regression parameter } & \multirow{3}{*}{$\begin{array}{l}\text { Lead } \\
\text { content } \\
(\text { mean } \pm \mathrm{SD}) \\
\mu \mathrm{g} \mathrm{g}^{-1} \\
\text { (GFAAS) }\end{array}$} \\
\hline & & & \multirow[b]{2}{*}{ Slope } & \multirow{2}{*}{$\begin{array}{l}\text { Intercept/ } \\
\left(10^{-8} \mathrm{~mol}\right. \\
\left.\mathrm{dm}^{-3}\right)\end{array}$} & \multirow{2}{*}{$\begin{array}{l}\text { Corr. } \\
\text { Coef. }\end{array}$} & \multicolumn{2}{|c|}{ Confidence } & \\
\hline & & & & & & Higher & Lower & \\
\hline $\mathrm{B}_{1}$ & 10 & $0.895 \pm 0.03$ & 21.10 & 92.5 & 0.9996 & 0.9320 & 0.8580 & $0.920 \pm 09.05$ \\
\hline $\mathrm{B}_{2}$ & 90 & $1.360 \pm 0.07$ & 2.30 & 152.3 & 0.9996 & 1.4500 & 1.2730 & $1.500 \pm 0.050$ \\
\hline $\mathrm{B}_{3}$ & 30 & $0.435 \pm 0.02$ & 2.40 & 50.0 & 0.9994 & 0.4600 & 0.4101 & $0.450 \pm 0.010$ \\
\hline $\mathrm{B}_{4}$ & 60 & $0.205 \pm 0.01$ & 5.42 & 55.0 & 0.9993 & 0.2174 & 0.1926 & $0.231 \pm 0.030$ \\
\hline $\mathrm{B}_{5}$ & 45 & $0.228 \pm 0.01$ & 4.70 & 50.0 & 0.9994 & 0.2404 & 0.2156 & $0.231 \pm 0.030$ \\
\hline $\mathrm{B}_{6}$ & 20 & $0.849 \pm 0.04$ & 3.08 & 127.5 & 0.9996 & 0.8987 & 0.7993 & $0.860 \pm 0.060$ \\
\hline $\mathrm{B}_{7}$ & 15 & $1.751 \pm 0.10$ & 6.45 & 55.0 & 0.9996 & 1.8750 & 1.6270 & $1.850 \pm 0.200$ \\
\hline $\mathrm{B}_{8}$ & 60 & $0.742 \pm 0.02$ & 1.10 & 40.0 & 0.9993 & 0.7669 & 0.7171 & $0.790 \pm 0.050$ \\
\hline $\mathrm{B}_{9}$ & 10 & $0.850 \pm 0.02$ & 0.96 & 40.0 & 0.9994 & 0.8749 & 0.8251 & $0.920 \pm 0.040$ \\
\hline $\mathrm{B}_{10}$ & 45 & $0.373 \pm 0.01$ & 1.82 & 35.0 & 0.9992 & 0.3854 & 0.3606 & $0.380 \pm 0.020$ \\
\hline
\end{tabular}

Table 3: Cadmium content of different boiling samples (a mean value \pm standard deviation for $\mathrm{n}=5$ at $95 \%$ confidence level)

\begin{tabular}{|c|c|c|c|c|c|c|c|c|}
\hline \multirow[b]{3}{*}{$\begin{array}{l}\text { Sample } \\
\text { No. }\end{array}$} & \multirow[b]{3}{*}{$\begin{array}{l}\mathrm{T}_{\mathrm{d}} \\
(\mathrm{sec})\end{array}$} & \multirow{3}{*}{$\begin{array}{l}\text { Cadmium } \\
\text { content } \\
(\text { mean } \pm S D) \pm \mathrm{g} \mathrm{g}^{-1} \\
(\mathrm{DPSAV})\end{array}$} & \multicolumn{5}{|c|}{ Regression parameter } & \multirow{3}{*}{$\begin{array}{l}\text { Cadmium } \\
\text { content } \\
(\text { mean } \pm \mathrm{SD}) \\
\mu \mathrm{g} \mathrm{g}^{-1} \\
(\text { GFAAS })\end{array}$} \\
\hline & & & \multirow[b]{2}{*}{ Slope } & \multirow{2}{*}{$\begin{array}{l}\text { Intercept/ } \\
\left(10^{-8} \mathrm{~mol}\right. \\
\left.\mathrm{dm}^{-3}\right)\end{array}$} & \multirow[b]{2}{*}{$\begin{array}{l}\text { Corr. } \\
\text { Coef. }\end{array}$} & \multicolumn{2}{|c|}{ Confidence } & \\
\hline & & & & & & Higher & Lower & \\
\hline $\mathrm{B}_{1}$ & 60 & $0.031 \pm 0.0010$ & 8.44 & 22.0 & 0.9992 & 0.0322 & 0.0298 & $0.035 \pm 0.002$ \\
\hline $\mathrm{B}_{2}$ & 90 & $0.044 \pm 0.0020$ & 4.83 & 20.0 & 0.9999 & 0.0465 & 0.0415 & $0.045 \pm 0.003$ \\
\hline $\mathrm{B}_{3}$ & 30 & $0.103 \pm 0.0080$ & 2.18 & 21.0 & 0.9995 & 0.1130 & 0.0930 & $0.085 \pm 0.009$ \\
\hline $\mathrm{B}_{4}$ & 120 & $0.103 \pm 0.0080$ & 5.21 & 22.0 & 0.9993 & 0.0487 & 0.0413 & $0.040 \pm 0.004$ \\
\hline $\mathrm{B}_{5}$ & 90 & $0.006 \pm 0.0005$ & 8.16 & 7.5 & 0.9991 & 0.0066 & 0.0054 & $0.006 \pm 0.006$ \\
\hline $\mathrm{B}_{6}$ & 120 & $0.042 \pm 0.0010$ & 10.09 & 42.5 & 0.9995 & 0.0432 & 0.0408 & $0.039 \pm 0.002$ \\
\hline $\mathrm{B}_{7}$ & 90 & $0.028 \pm 0.0030$ & 6.65 & 16.0 & 0.9994 & 0.0317 & 0.0243 & $0.025 \pm 0.003$ \\
\hline $\mathrm{B}_{8}$ & 60 & $0.020 \pm 0.0020$ & 3.47 & 7.0 & 0.9994 & 0.0225 & 0.0175 & $0.021 \pm 0.003$ \\
\hline $\mathrm{B}_{9}$ & 60 & $0.006 \pm 0.0002$ & 6.35 & 5.0 & 0.9993 & 0.0063 & 0.0058 & $0.006 \pm 0.001$ \\
\hline $\mathrm{B}_{10}$ & 60 & $0.046 \pm 0.0030$ & 3.81 & 16.0 & 0.9992 & 0.0497 & 0.0423 & $0.045 \pm 0.004$ \\
\hline
\end{tabular}

Table 4: Copper content of different boiling samples (a mean value \pm standard deviation for $\mathrm{n}=5$ at $95 \%$ confidence level)

\begin{tabular}{|c|c|c|c|c|c|c|c|c|}
\hline \multirow[b]{3}{*}{$\begin{array}{l}\text { Sample } \\
\text { No. }\end{array}$} & \multirow[b]{3}{*}{$\begin{array}{l}\mathrm{T}_{\mathrm{d}} \\
(\mathrm{sec})\end{array}$} & \multirow{3}{*}{$\begin{array}{l}\text { Copper } \\
\text { content } \\
(\text { mean } \pm \mathrm{SD}) \\
\mu \mathrm{g} \mathrm{g}^{-1} \\
(\mathrm{DPSAV})\end{array}$} & \multicolumn{5}{|c|}{ Regression parameter } & \multirow{3}{*}{$\begin{array}{l}\text { Copper } \\
\text { content } \\
(\text { mean } \pm \text { SD) } \\
\mu \mathrm{g} \mathrm{g}^{-1} \\
(\text { FAAS) }\end{array}$} \\
\hline & & & \multirow[b]{2}{*}{ Slope } & \multirow{2}{*}{$\begin{array}{l}\text { Intercept/ } \\
\left(10^{-8} \mathrm{~mol}\right. \\
\left.\mathrm{dm}^{-3}\right)\end{array}$} & \multirow[b]{2}{*}{$\begin{array}{l}\text { Corr. } \\
\text { Coef. }\end{array}$} & \multicolumn{2}{|c|}{ Confidence } & \\
\hline & & & & & & Higher & Lower & \\
\hline $\mathrm{B}_{1}$ & 10 & $1.135 \pm 0.05$ & 18.20 & 320 & 0.9994 & 1.1970 & 1.073 & $1.050 \pm 0.07$ \\
\hline $\mathrm{B}_{2}$ & 45 & $0.436 \pm 0.01$ & 46.90 & 320 & 0.9995 & 0.4480 & 0.424 & $0.419 \pm 0.02$ \\
\hline $\mathrm{B}_{3}$ & 10 & $1.870 \pm 0.20$ & 8.65 & 250 & 0.9994 & 2.1190 & 1.621 & $1.950 \pm 0.30$ \\
\hline $\mathrm{B}_{4}$ & 15 & $2.124 \pm 0.20$ & 11.67 & 390 & 1.0000 & 2.3730 & 1.875 & $2.010 \pm 0.40$ \\
\hline $\mathrm{B}_{5}$ & 30 & $1.480 \pm 0.08$ & 15.95 & 380 & 0.9994 & 1.5795 & 1.381 & $1.550 \pm 0.06$ \\
\hline $\mathrm{B}_{6}$ & 15 & $0.198 \pm 0.02$ & 25.80 & 80 & 0.9998 & 0.2230 & 0.173 & $0.210 \pm 0.03$ \\
\hline $\mathrm{B}_{7}$ & 40 & $0.219 \pm 0.01$ & 90.90 & 300 & 0.9995 & 0.2314 & 0.207 & $0.202 \pm 0.03$ \\
\hline $\mathrm{B}_{8}$ & 10 & $0.320 \pm 0.01$ & 19.34 & 100 & 0.9996 & 0.3324 & 0.308 & $0.290 \pm 0.03$ \\
\hline $\mathrm{B}_{9}$ & 20 & $0.402 \pm 0.01$ & 42.84 & 260 & 0.9994 & 0.4154 & 0.391 & $0.380 \pm 0.02$ \\
\hline $\mathrm{B}_{10}$ & 15 & $0.750 \pm 0.02$ & 21.20 & 260 & 0.9996 & 0.7749 & 0.725 & $0.760 \pm 0.05$ \\
\hline
\end{tabular}

limits of detection of the proposed procedure for lead ions under investigation were calculated. The concentration of $\mathrm{Pb}(\mathrm{II})$ ions in all samples under consideration using DPASV are shown in Table 2. It was found that, the mean levels of $\mathrm{Pb}$ (II) ions are ranged from $0.205-1.751 \mu \mathrm{g} \mathrm{g}^{-1}$ and the lead content increases in the following order, $\mathrm{B}_{4}<\mathrm{B}_{5}<\mathrm{B}_{10}<\mathrm{B}_{3}<\mathrm{B}_{8}<\mathrm{B}_{6}<\mathrm{B}_{9}<\mathrm{B}_{1}<\mathrm{B}_{2}<\mathrm{B}_{7}$. Thus lead content increase in whole herb and flowering heads, while it decreases in the leaves. The average concentrations of $\mathrm{Pb}(\mathrm{II})$ in all samples under investigation within the safe limits set by FAO/WHO.

DPASV voltammetric determination of $\mathrm{Cd}(\mathrm{II})$ : Figure 4 shows the differential pulse anodic stripping voltammograms of $\mathrm{Cd}(\mathrm{II})$ in $\mathrm{B}_{2}$ sample spiked with different concentration of cadmium ions in BritonRobinson Buffer Solution of $\mathrm{pH} \sim 2$.1. On plotting of $\mathrm{i}_{\mathrm{p}}$ vs. $\mathrm{Cd}(\mathrm{II})$ concentrations for all medicinal herb samples in the same supporting electrolyte at the same 


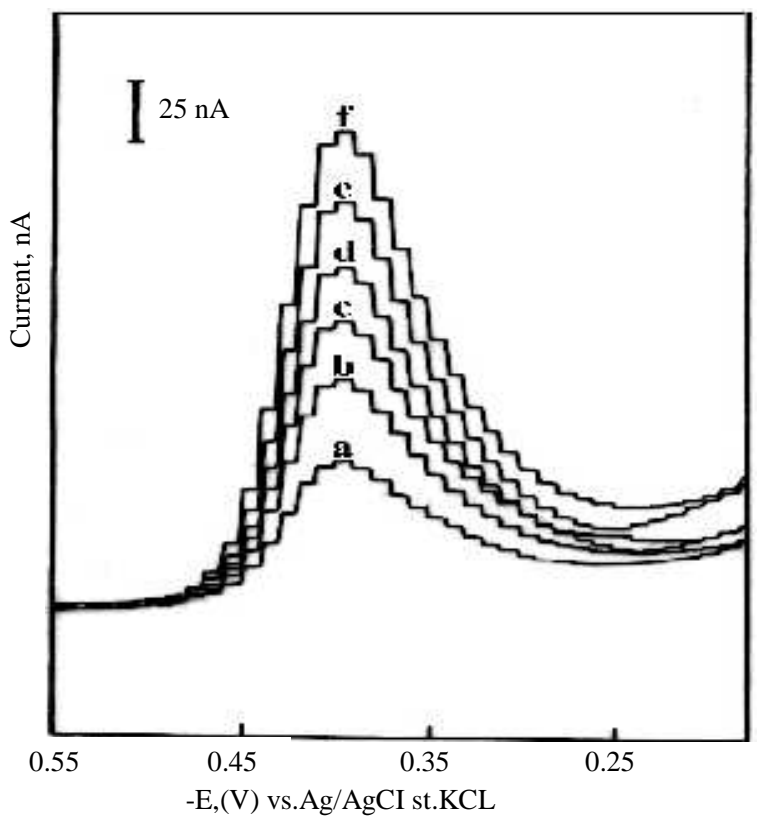

Fig. 2: DPAS Voltammograms of $\mathrm{Pb}(\mathrm{II})$ in $\mathrm{B}_{3}$ sample spiked with different concentrations of $\mathrm{Pb}$ (II) ions in $0.028 \mathrm{M}$ Briton-Robinson buffer solution, $\mathrm{pH} \sim 2.1$ at deposition potential $-0.55 \mathrm{~V}$ and deposition time $30 \mathrm{sec}$. (a): Sample, $\mathrm{S}$ (b): $\mathrm{S}+10 \times 10^{-8}$, (c): $\mathrm{S}+20 \times 10^{-8}$,

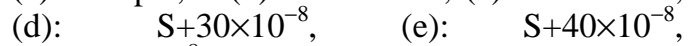
(f): $\mathrm{S}+5 \times 10^{-8} \mathrm{M} \mathrm{Pb}$ (II)

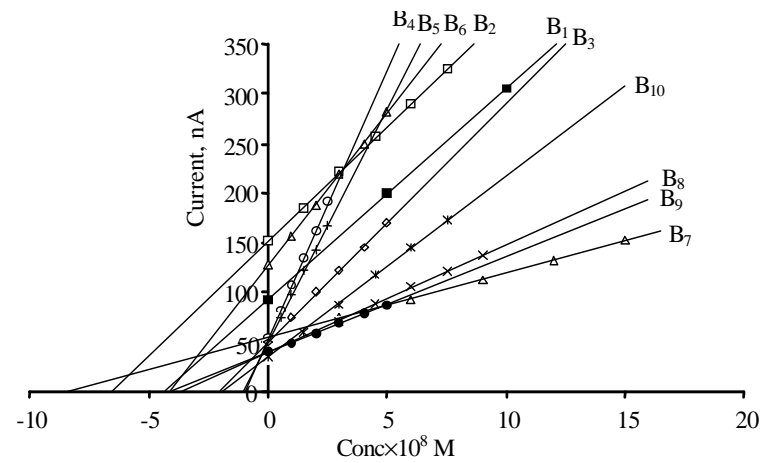

Fig. 3: Standard addition plot of $\mathrm{Pb}(\mathrm{II})$ in samples: (1): $B_{1}$ at $10 \mathrm{sec},(2): B_{2}$ at $90 \mathrm{sec},(3): B_{3}$ at 30 $\mathrm{sec},(4): \mathrm{B}_{4}$ at $60 \mathrm{sec},(5): \mathrm{B}_{5}$ at $45 \mathrm{sec},(6): \mathrm{B}_{6}$ at $20 \mathrm{sec},(7): \mathrm{B}_{7}$ at $15 \mathrm{sec},(8): \mathrm{B}_{8}$ at $60 \mathrm{sec}$, (9): $\mathrm{B}_{9}$ at $10 \mathrm{sec},(10): \mathrm{B}_{10}$ at $45 \mathrm{sec}$, at deposition potential $-0.55 \mathrm{~V}$ using (DPASV)

conditions, straight lines are obtained (standard addition method) as shown in Fig. 5. From the interceptions of these lines with the concentration axis at zero current signals, one can calculate the concentration of $\mathrm{Cd}(\mathrm{II})$ in

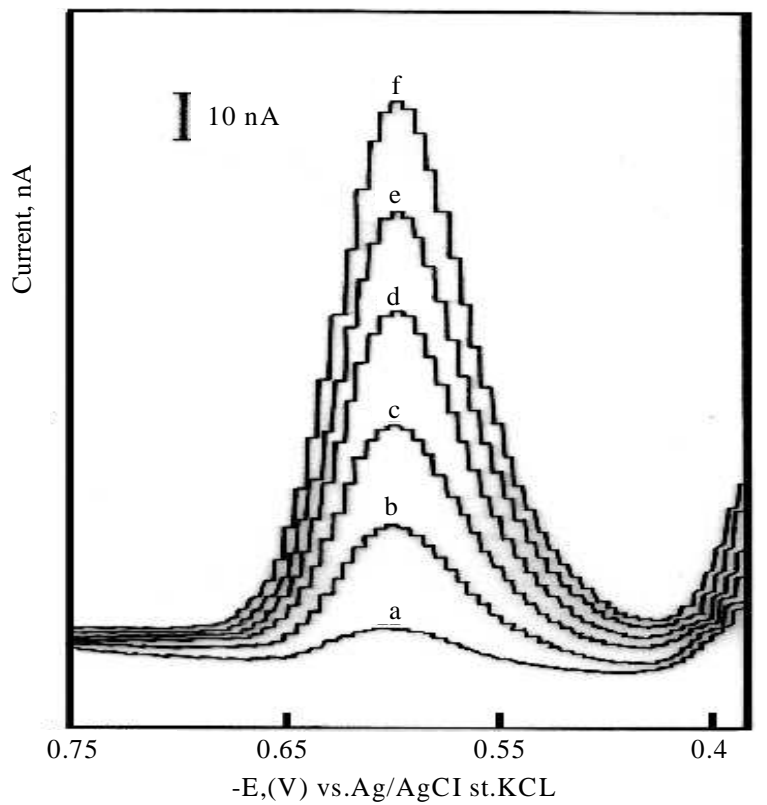

Fig. 4: DPAS Voltammograms of $\mathrm{Cd}(\mathrm{II})$ in $\mathrm{B}_{2}$ sample spiked with different concentrations of Cd(II)ions in $0.028 \mathrm{M}$ Briton-Robinson buffer solution, $\mathrm{pH} \sim 2.1$ at deposition potential $-0.75 \mathrm{~V}$ and deposition time $90 \mathrm{sec}$.

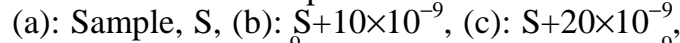

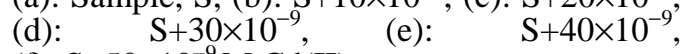
(f): $\mathrm{S}+50 \times 10^{-9} \mathrm{M} \mathrm{Cd}(\mathrm{II})$

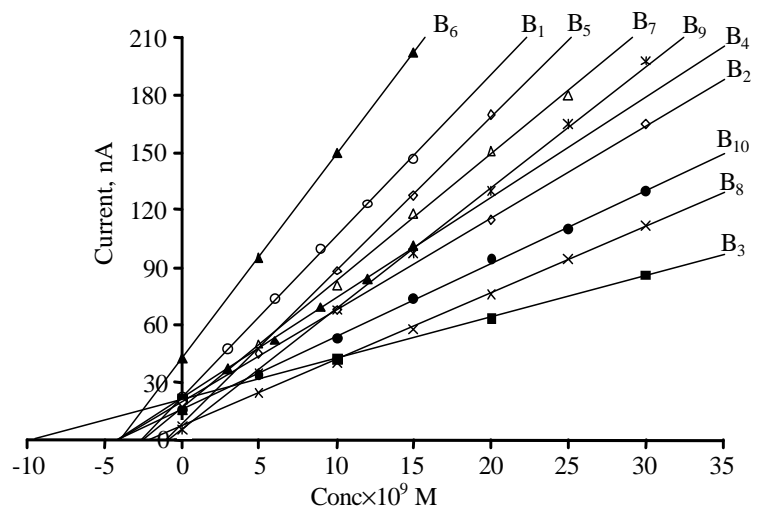

Fig. 5: Standard addition plot of $\mathrm{Cd}(\mathrm{II})$ in samples: (1): $\mathrm{B}_{1}$ at $60 \mathrm{sec},(2): \mathrm{B}_{2}$ at time $90 \mathrm{sec},(3): \mathrm{B}_{3}$ at $30 \mathrm{sec},(4): \mathrm{B}_{4}$ at $120 \mathrm{sec},(5): \mathrm{B}_{5}$ at $90 \mathrm{sec}$, (6): $\mathrm{B}_{6}$ at $120 \mathrm{sec},(7): \mathrm{B}_{7}$ at $90 \mathrm{sec},(8): \mathrm{B}_{8}$ at $60 \mathrm{sec},(9): \mathrm{B}_{9}$ at $60 \mathrm{sec},(10): \mathrm{B}_{10}$ at $60 \mathrm{sec}$, at deposition potential -0.75 V using (DPASV)

each sample. The result of concentration values in $\mu \mathrm{g}$ $\mathrm{g}^{-1}$ are listed in Table 3. The results indicated that, the $\mathrm{Cd}(\mathrm{II})$ contents are ranging from $0.006-0.103 \mu \mathrm{g} \mathrm{g}^{-1}$ and the cadmium content increases in the following 


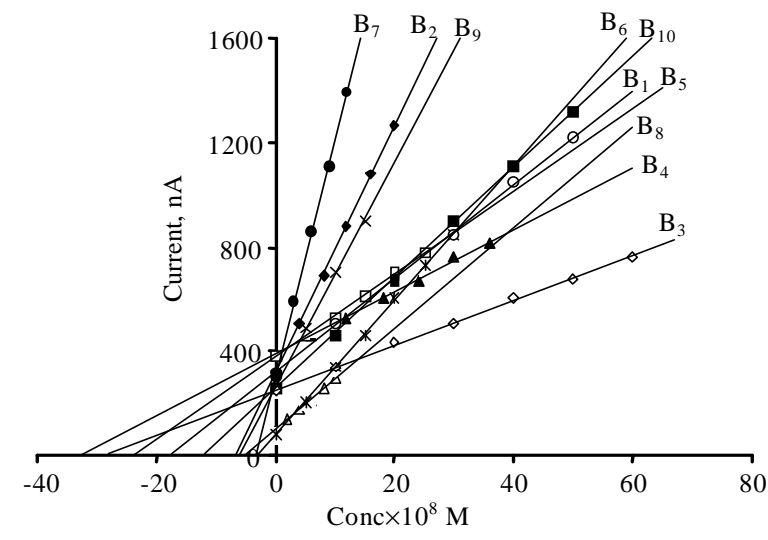

Fig. 6: Standard addition plot of $\mathrm{Cu}(\mathrm{II})$ in samples: (1): $B_{1}$ at $10 \mathrm{sec},(2): B_{2}$ at $40 \mathrm{sec},(3): B_{3}$ at $10 \mathrm{sec},(4): \mathrm{B}_{4}$ at $15 \mathrm{sec},(5): \mathrm{B}_{5}$ at $30 \mathrm{sec}$, (6): $\mathrm{B}_{6}$ at $15 \mathrm{sec},(7): \mathrm{B}_{7}$ at $40 \mathrm{sec},(8): \mathrm{B}_{8}$ at $10 \mathrm{sec}$, (9): $\mathrm{B}_{9}$ at $20 \mathrm{sec},(10): \mathrm{B}_{10}$ at $15 \mathrm{sec}$, at deposition potential $-0.25 \mathrm{~V}$ using (DPASV)

order $\mathrm{B}_{5}=\mathrm{B}_{9}<\mathrm{B}_{8}<\mathrm{B}_{7}<\mathrm{B}_{1}<\mathrm{B}_{6}<\mathrm{B}_{2}<\mathrm{B}_{4}<\mathrm{B}_{10}<\mathrm{B}_{3}$. Thus, cadmium content increases in the whole herb without roots and decreases in the leaves. The results also indicated that, cadmium content in the medicinal herb samples are less than the permissible values were given by WHO and FAO.

DPAS voltammetric determination of $\mathrm{Cu}$ (II): Figure 6 shows the standard addition plots of ip against $\mathrm{Cu}$ (II) concentration for ten medicinal herb sample solutions in Briton-Robinson buffer solution of $\mathrm{pH} \sim 2.1$ at deposition potential -0.25 volt. From the interceptions of these straight lines with the concentration axis at zero current signals, the concentration of each sample in $\mu \mathrm{g} \mathrm{g}^{-1}$ was calculated and the resulting concentration values are listed in Table 4. The results indicate that, the $\mathrm{Cu}$ (II) concentrations are ranging from 0.198-2.124 $\mu \mathrm{g} \mathrm{g}^{-1}$, which are less than the permissible values are given by WHO and FAO.

The results also indicate that, the divalent copper content increases in the following order $\mathrm{B}_{6}<\mathrm{B}_{7}<\mathrm{B}_{8}<\mathrm{B}_{9}<\mathrm{B}_{2}<\mathrm{B}_{10}<\mathrm{B}_{1}<\mathrm{B}_{5}<\mathrm{B}_{3}<\mathrm{B}_{4}$. Thus $\mathrm{Cu}(\mathrm{II})$ contents increases in the leaves and decreases in the flowering plant without roots.

The precision and reproducibility of the selected procedure were investigated by measuring the concentration of $\mathrm{Cd}(\mathrm{II}), \mathrm{Pb}(\mathrm{II})$ and $\mathrm{Cu}(\mathrm{II})$ in all medicinal herb samples under consideration for $(n=5)$. The values of slopes, intercepts, confidence intervals, standard deviations and correlation coefficients obtained for all samples are listed in Table 2-4. These statistical parameter values indicate the reproducibility of the procedure for determination of each of $\mathrm{Cd}(\mathrm{II})$, $\mathrm{Pb}$ (II) and $\mathrm{Cu}(\mathrm{II})$ in all samples in this Briton-Robinson buffer solution, $\mathrm{pH} \sim 2.1$.

Flame atomic absorption spectrometric determination of copper: Copper was determined by atomic absorption spectroscopy of the treated sample solutions at $324.7 \mathrm{~nm}$. The concentration values of each sample are listed in Table 4. It was found that the concentration of copper is ranged between $0.202-2.010 \mu \mathrm{g} \mathrm{g}^{-1}$. From Table 4, it was found that, the data obtained by stripping voltammetry are in a close agreement with those obtained by flame atomic absorption spectrometry. However, the slight differences that found in some cases are mainly due to the manipulation of the analyst and the use of the calibration curves in the case of flame atomic absorption spectrometry.

Flame atomic absorption spectrometric method was not obeyed for determination of cadmium and lead, so the concentration of each cadmium and lead is less than the detection limits of the FAAS technique.

Graphite furnace atomic absorptionspectrometric determination of cadmium and lead: Cadmium and lead were determined by graphite furnace atomic absorption spectrometry at 228.9 and $283.2 \mathrm{~nm}$ respectively. The resulting data were listed in Table 2 and 3. From Table 2, it was found that, the resulting data obtained by stripping voltammetry are in a close agreement with those obtained by graphite furnace atomic absorption spectrometry. However, the slight difference that found in some cases are mainly due to manipulation of the analyst and the use of the calibration curve in the case of graphite furnace atomic absorption spectrometry instead of the standard addition method, which is more accurate than the calibration curves.

From Table 3, it was found that the resulting data obtained by stripping voltammetry is mainly less than that obtained by graphite furnace atomic absorption spectrometry due to the same reasons discussed above for cadmium as well as there is an another factor: in case of stripping voltammetry only divalent lead was detected but in the case of GFAAS, all lead species in the sample solution were detected.

The foregoing results reveal that, the stripping voltammetric approach accurate, low maintain cost, rapid reproducible, highly sensitivity and selective method for monitoring of the trace elements, cadmium, lead and copper in medicinal herbs. The results also indicate that, copper, cadmium and lead contents in the 
samples are less than that permissible values which given by WHO and FAO and differ from each other's according to its environment contamination, production and storage.

\section{ACKNOWLEDGEMENT}

The authors wish to thank Prof. Dr. Mahmoud A. Ghandour and Prof. Dr. Rabie M. Gabr for their keen interest and help in this work.

\section{REFERENCES}

1. David, R.L., 2005. CRC Handbook of Chemistry and Physics. 86th Edn. Florence, Kentucky, USA.

2. Nordberg, G.F. and M. Nordberg, 1988. Biological Monitoring of Cadmium. In: Biological Monitoring of Toxic Metals. Plenum Press, New York.

3. Ades, A.E. and G. Kazantzis, 1998. Br. J. Ind. Med., 45: 435.

4. Ellis, K.J., Morgan W.D., Zanzi, I., Yasumura, S., Vartsky, D. and Cohn, S. H.1980. Am. J. Ind. Med., 1,339.

5. Foulkes, E.C., 1990. Crit Rev. Toxicol, 20: 327.

6. Lauwerys, R.R. and A.M. Bernard, 1986. Br. J. Ind. Med., 43: 433.

7. McCann, M., 1990. Cadmium Hazards. Art Hazards New, 13: 2.

8. Sullivan, K. and L. Waterman, 1988. Ann. Occup. Hyg., 32: 557.

9. Liobet, J. M., Domingo, J.L., Paternain, J. L. and Corbella, J., 1990. Environ Contam Toxicol, 19(2), 185.

10. Simon, J.A. and Hudes, E.S. 1999. JAMA, 281: 2289.

11. Barry, B. S. I. 1975. Br. Ind. Med., 32,119.

12. Batuman V., Maesaka, J. K. and Haddad B., et. al. 1981. N Engl. J. Med., 304, 520.

13. Bennett, W. M., 1985. Kidney Int., 28, 212.

14. Flegal, A.R. and Smith, D. R.1995. Rev Environ Contam Toxicol, 143, 1.

15. Hu, H., Aro, A. and Payton, M., et. al. 1996. JAMA, 275, 1171.

16. Wilson, L. 1998. Nutritional balancing and hair mineral analysis, L. D. Wilson Consultants.

17. Eck, P. and Wilson, L. 1989. Toxic metals in human health and disease, Eck Institute of Applied Nutrition and Bioenergetics, Ltd., Phoenix, AZ.

18. Pfeiffer, C. 1975. Metal and element nutrients. 1975. Keats Publishing, New Canaan, Ct.

19. Rajurkar, N. S. and Damame, M. M. 1998. Applied Radiation and Isotopes, 49(7), 773.

20. Singh, V. and Garg, A. N. 1997. ibid, 48(1), 97.

21. Shallari, S., Schwartz, C., Hasko, A. and Morel, J. L. 1998. The Science of the Total Environment, 209, 133.

22. Özcan, M. 2004. Food Chemistry, 84, 437.

23. Ražić, S. Onjia, A., Dogo, S., Slavković, L. and Popović, A. 2005. Talanta, 67, 233.
24. Başgel, S. and Erdemoğlu, S. B. 2006. Science of the Total Environment, 359(1-3), 82.

25. Lozak, A. Soltyk, K., Ostapczuk, P. and Fijalek, Z. 2002. ibid, 289, 33.

26. Soltyk, K., Lozak, A., Ostapczuk, P. and Fijalek, Z. 2003. Journal of Pharmaceutical and Biomedical Analysis, 32, 425.

27. Wesolowski, M. and Konièczyński, P. Thermochimica Acta, 397, 171.

28. Wesolowski, M. and Konièczyński, P. 2003. International Journal of Pharmaceutics, 262, 29.

29. Ansari, T. M., Ikram, N., Najam al-Hag, M., Fayyaz, I., Fayyaz, Q., Ghafoor, I. and Khalid, N. 2004. Journal of Biological Sciences, 4(2), 95.

30. Kumar, A., Nair, A. G. C., Reddy, A. V. R. and Garg, A. N. 2005. Journal of Pharmaceutical and Biomedical Analysis, 37, 631.

31. Obi, E., Akunyili, D. N. Ekpo, B. and Orisakwe, O.E. 2006. Science of the Total Environment, 369, 35.

32. Fuh, C. B., Lin, H. I. and Tsai, H. 2003. Journal of Food and Drug Analysis, 11(1), 39.

33. Gomez, M. R., Cerutti, S., Olsina, R. A., Silva, M.F. and Martinez, L. D. 2004. Journal of Pharmaceutical and Biomedical Analysis, 34, 569.

34. Caladas, E. D. and Machado, L. L. 2004. Food and Chemical Toxicology, 42, 599.

35. Ajasab, M.O., Bello, M.O., Ibrahim, A.O. Ogunwande, I.A. and Olawore, N.O. 2004. Food Chemistry, 85, 67.

36. Ražić, S. Onjia, A. and Potkonjak, B. 2003. Journal of Pharmaceutical and Biomedical Analysis, 33, 845.

37. Calaa, V., Casesb, M. A. and Walterb, I. 2005. Journal of the Arid Environments, 62, 401.

38. Suchacz, B. and Wesolowski, M. 2006. Talanta, 69, 37.

39. Mamani, M. C. V., Aleixo, L. M. and Abreu, M. F. du. 2005. Journal of Pharmaceutical and Biomedical Analysis, 37, 709.

40. Hassan, A. 1991. Polarographic behavior and determination of selenite and tellurite in simple solution or in a binary mixture, Monatshefte Für Chemie, 122, 605.

41. El-Shatoury, S. A. and Hassan, A. 1993. Electrochemical behaviour and determination of trivalent antimony in aqueous solutions, Bull. Pol. Acad. Sci. chem.., 41(3), 145.

42. Hassan, A. 1996. Electrochemical behaviour and determination of hexavalent uranium in aqueous solutions, Bull. Fac. Sci., Assiut Univ., 25(1), 11.

43. Hassan, A. 2007. Determination of trivalent aluminum and divalent zinc in drinking waters by differential pulse stripping voltammetry, American Journal of Applied Sciences, 4(4), 245.

44. Vogel, A. I. 1978. A Textbook of Quantitative Inorganic Analysis $4^{\text {th }}$ Ed., Longman, London.

45. Ali, A. E., Khayamian, T. and Shokooh, S. K. 2004. Analytical Chimica Acta, 505, 201. 